\title{
GENERA PLEUROTHALLIDINARUM: AN UPDATED PHYLOGENETIC OVERVIEW OF PLEUROTHALLIDINAE
}

\author{
AdAM P. KARREMANS \\ Lankester Botanical Garden, University of Costa Rica, P.O. Box 302-7050 Cartago, Costa Rica. \\ Naturalis Biodiversity Center, Leiden, The Netherlands• adam.karremans@ucr.ac.cr
}

\begin{abstract}
Subtribe Pleurothallidinae with just over 5000 species is possibly the most species-rich of all orchids. It has been growing steadily for more than two centuries, but the last three decades have been especially active in terms of systematic and phylogenetic studies in the group. The growth in species numbers has been accompanied by the marked increase in generic and infrageneric concepts. Nevertheless, Pleurothallidinae are plagued with cases of convergent and divergent morphology, and phylogenetic relatedness is not always apparent. This opens the door to controversial changes in generic circumscriptions that are considered too inclusive by some and too exclusive by others. A grave consequence of these disagreements is the difficulty of assessing which and how many species actually belong to each genus. Here an attempt is made to place generic names among their close relatives as a first step to re-evaluating the whole subtribe.
\end{abstract}

Key words: Acianthera, Anathallis, Dilomilis, Masdevallia, Octomeria, Phloeophila, Pleurothallis, Restrepia, Specklinia, systematics

Introduction. Pleurothallis R.Br., the type genus of subtribe Pleurothallidinae Lindl., was described more than two centuries ago. Historically, Pleurothallis and Pleurothallidinae have been treated almost as synonyms, with the exclusion of only a few morphologically well-recognizable genera from Pleurothallis over the centuries. The first systematic classification of the members of Pleurothallidinae is possibly that of Lindley (1842, 1859). Several authors followed with additional proposals to tackle Pleurothallis and its segregate genera (i.e. Reichenbach, Barbosa Rodrigues, Cogniaux, Schlechter, Garay, Dressler, and others). Members of the genus had, however, not undergone as many changes as they have in the last three decades. Luer's first monographs of the group in 1986 (Luer 1986a, 1986b, 1986c) triggered a proliferation of systematic studies in the subtribe which would have been impossible before. Dozens of monographs followed. The first molecular phylogeny was published by Pridgeon, Solano and Chase in 2001 and was followed by a proposal to redefine the whole subtribe (Pridgeon \& Chase 2001). However, the significant systematic and taxonomic changes proposed after that, in addition to the rapid increase in species numbers within Pleurothallidinae, has more than ever fueled the need for a comprehensive picture of phylogenetic relationships within the subtribe.

This issue with the classification of the megadiverse Pleurothallis (in a traditional sense) has historically been the same one: the realization that it is not monophyletic but that there was no consistent way to resolve the systematics of the group with the available data. In 1859, Lindley said about Pleurothallis "I think it necessary to preserve this great and difficult genus without dismemberment. Not that I regard it as a really single aggregation of species...." A century later Luer himself would state that "Pleurothallis is indeed capable of being divided, but because of the various interrelationships, most divisions at the subgeneric and sectional levels seem more practical" and added, "A Pleurothallis might be described as any pleurothallid that does not fit into any of the other genera" (Luer 1986c). After their morphologically based cladistic study of the group, Neyland et al. (1995) also noted that "the large genus Pleurothallis is polyphyletic and, therefore, may be divided into several genera", while in his palynological study of the subtribe Stenzel (2000) would suggest that "the genus comprises a combination of morphologically rather underived sister taxa of the other pleurothallid genera". But, it was not until Pridgeon and Chase 
(2001), based on the molecular studies by Pridgeon et al. (2001), that Pleurothallis was finally dismembered. The authors noted that it "has been nothing but a polymorphic assemblage for almost two centuries" and that "many taxa with conspicuous autapomorphies were segregated from it, gradually leaving the genus itself with no defining synapomorphies."

Pridgeon and Chase (2001) argued that "many characters are difficult to score in cladistic analyses because they are either continuous or probably not homologous. These same characters show up repeatedly in his [Luer's] artificial key to the subgenera." Nevertheless, the complexity of the group and their limited sampling size forced them to admit that "for nomenclatural transfers we extrapolated from the study taxa to morphologically similar taxa as recognized by Luer." Not surprisingly, subsequent phylogenetic studies within the Pleurothallidinae have shown that the generic, subgeneric and sectional systematics of the subtribe were not fully resolved. Recircumscriptions and emendations were either made or at least suggested by several authors who used novel analytical methods and/or included a broader sampling of species (Stenzel 2004, Abele 2007, Karremans 2010, 2014, Chiron et al. 2012, Karremans et al. 2013a, 2013b, Wilson et al. 2013, Karremans \& RincónGonzález 2015, Chiron et al. 2016, Karremans et al. in press). Meanwhile, hundreds of species' names, either new species or combinations, and dozens of new genera have since then been proposed by Luer (2002a, 2004, 2005, 2006, 2007, 2009) and others, mostly but not exclusively, on the basis of morphology.

There is a pressing need for reviewing the phylogenetic relationships of many groups within the pleurothallids. Nowadays authors are frequently compelled by editors and reviewers to use so-called "widely accepted" names. Those names frequently follow particular databases or comprehensive rather than specialized monographic works. Although this tendency might be understandable, it is not in the best interest of the scientific community. If one were to follow the WCSP, to cite an example of a database used as a reference by several journals, one would soon get into trouble. Under the synonymy of genus Pleurothallis, for example, are many genera that we know are not even closely related. The list includes Antilla (Luer) Luer, Apoda-prorepentia (Luer) Luer and Pleurobotryum
Barb.Rodr., phylogenetically related to Acianthera; it also lists Areldia Luer, Cucumeria Luer, Gerardoa Luer and Rubellia (Luer) Luer, which are actually Specklinia Lindl. relatives; Andreettaea Luer, with unknown affinity, and Sansonia Chiron, basal in the pleurothallids, are also placed under Pleurothallis even though clearly not related to that genus. Most of these genera have been argued and proven to be distinct in different papers published mostly after Genera Orchidacearum (Pridgeon 2005). The basis for their establishment has been morphological or molecular, and sometimes both. The issue with Pleurothallidinae goes much further than choosing a particular classification system. Different classification systems should be alternative, but never conflicting. Say that system A proposes a single genus (1), whereas system B proposes two genera (1 and 2). In alternative proposals the same species are included in each system; in system A all of them are included in a single genus (genus 1), and in system B the same species are segregated into two genera (1 and 2). This means that the formula $\mathrm{A} 1=\mathrm{B} 1+\mathrm{B} 2$ is true. In contrast, in conflicting proposals that formula does not hold true. For example, the monophyletic genus Phloeophila (sensu Pridgeon 2005) could be otherwise interpreted as the sum of the also monophyletic genera Luerella Braas, Ophidion Luer and Phloeophila Hoehne \& Schltr. These proposals are therefore alternative. However, the generic concept of Specklinia (sensu Pridgeon 2005) is not equal to the sum of Acostaea Schltr., Empusella (Luer) Luer, Gerardoa, Muscarella Luer, Sarcinula Luer, Specklinia and Sylphia Luer (sensu Luer 2006), because many species included by one were excluded by the other. Unfortunately most current generic circumscriptions in the pleurothallids are conflicting. This is also the reason why it is difficult to determine how many accepted species the subtribe has, let alone how many accepted species belong in each genus.

It is to be expected that more inclusive generic concepts are more likely to be monophyletic than narrow generic concepts. That, together with fact that broader generic concepts will intrinsically reduce the number of generic names to be used, has led the community to prefer a conservative, more inclusive, approach. This is especially true when so called "splinter" genera are neither phylogenetically placed nor proven monophyletic. Nevertheless, broad is not always better. In a world where species can only 
be placed among their close relatives using DNA barcoding, students and hobbyists alike are faced with the everyday problem of not being able to place the right name tags on their plants. When genera are extremely inclusive and lack distinct morphological synapomorphies they become undiagnosable. It is made worse when no subgeneric classification is proposed. In that sense, information is key. Every species should be placed in a discrete grouping, be it at generic or subgeneric level, making it possible to find that species, and its relatives. In turn, each grouping should convey underlying information about the evolutionary history, distribution, ecology, etc. about the species assigned to it. They are otherwise useless.

In the midst of preparing a comprehensive systematic treatment of the Pleurothallidinae (Karremans, in prep.), an overview of the major affinities within the subtribe is presented here.

\section{Subtribe Pleurothallidinae Lindl.}

(Edward's Bot. Reg. 15: tab. 1298, 1829, nom. nud); Gen. Sp. Orch. Pl. 3. 1830.

Type: Epidendrum ruscifolium Jacq., Enum. P1. Carib. 29, 1760. [= Pleurothallis ruscifolia (Jacq.) R.Br. in Aiton, Hort. Kew. ed. 2, 5: 211. 1813.]

Ety.: From the Greek pleurothallos, "riblike branches" referring to the caespitose, slender ramicauls found in P. ruscifolia and in most of the Pleurothallidinae.

Plants perennial, epiphytic to lithophytic. Rhizome abbreviated to repent. Roots velamentous. Ramicauls non-pseudobulbous, cylindric, sheathed, mostly unifoliate. Leaf coriaceous, conduplicate, articulate. Inflorescence lateral or terminal, rarely basal on the stem, racemose, frequently successive. Flowers generally resupinate. Ovary articulated with the pedicel, cylindric. Column stout or elongate, subterete, the base footless to having a prominent foot. Anther dorsal, apical or ventral. Stigma apical or ventral, solitary, lobed. Pollinia 2, 4, 6 or 8, suborbicular to ovoid, rarely without caudicles, sometimes also with a viscidium. Fruits ellipsoid.

Generalities. In 1986, Luer accounted for as many as 4000 species in subtribe Pleurothallidinae. About two decades later Pridgeon (2005) increased the number to 4100 species. Today, 30 years after Luer's monograph, just over 5100 species (5114 today to be precise) are currently being accepted among the 12,000 published names applicable to the subtribe (Karremans, in prep.; Table 1). This number will probably increase by a few hundred in the next couple of decades as species complexes are studied more carefully and more literature on the Pleurothallidinae becomes available. As treated here, Lepanthes and Stelis each represent just over $20 \%$ of the species belonging to the subtribe, both with just above 1000 species (Fig. 1). Masdevallia and Pleurothallis each represent above $10 \%$ of the subtribe, both with around 500-600 species. There are eight other genera with more than 100 species each: Acianthera, Anathallis, Dracula, Octomeria, Pabstiella, Platystele, Specklinia and Trichosalpinx; they represent from $2 \%$ to $6 \%$ of the subtribe.

A major challenge within Pleurothallidinae is finding and defining phylogenetically informative, synapomorphic, morphological features. The recent molecular-based phylogenies have shown that many traditionally considered diagnostic morphological characters have appeared more than once independently

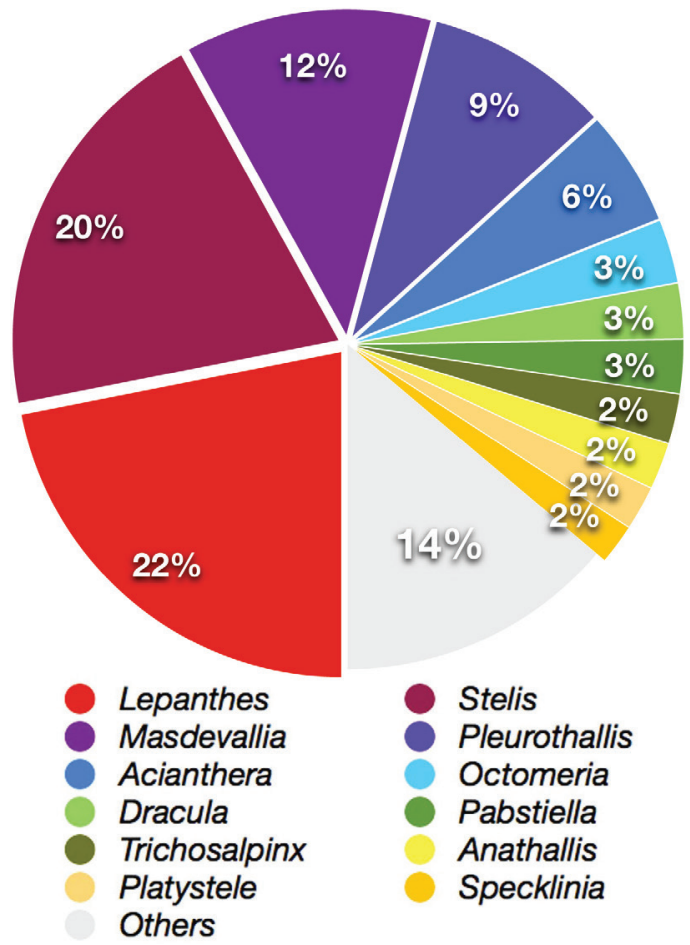

FIgURE 1. Relative species richness per genus in the Pleurothallidinae as currently defined. 
TABLE 1. Accepted number of species per genus in the Pleurothallidinae at the time of preparation of this manuscript (Karremans, in prep.).

\begin{tabular}{lc|lc} 
Genus & Species Number & Genus & Species Number \\
\hline Acianthera & 291 & Muscarella & 54 \\
Anathallis & 116 & Myoxanthus & 49 \\
Andinia & 71 & Neocogniauxia & 2 \\
Andreettaea & 1 & Octomeria & 159 \\
Atopoglossum & 3 & Pabstiella & 138 \\
Barbosella & 21 & Phloeophila & 9 \\
Brachionidium & 79 & Platystele & 110 \\
Chamelophyton & 1 & Pleurothallis & $465^{\star *}$ \\
Dilomilis & 5 & Pleurothallopsis & 18 \\
Diodonopsis & 5 & Porroglossum & 52 \\
Dondodia & 1 & Restrepia & 55 \\
Draconanthes & 2 & Restrepiella & 3 \\
Dracula & 134 & Sansonia & 2 \\
Dresslerella & 13 & Scaphosepalum & 50 \\
Dryadella & 57 & Specklinia & 100 \\
Echinosepala & 12 & Stelis & $1027^{\star * *}$ \\
Frondaria & 1 & Teagueia & 14 \\
Kraenzlinella & 11 & Tomzanonia & 1 \\
Lankesteriana & 21 & Trichosalpinx & 123 \\
Lepanthes & 1120 & Trisetella & 24 \\
Lepanthopsis & 44 & Zootrophion & 26 \\
Madisonia & 1 & & \\
Masdevallia & $623^{*}$ & TOTAL & $\mathbf{5 , 1 1 4}$
\end{tabular}

*At the time of preparation of this manuscript the total species number for genus Masdevallia had not been revised thoroughly. **The number of species attributed to Pleurothallis excludes those names that have not been placed elsewhere but most like do not belong in the genus. At least a few dozen names can be attributed to a so called "unplaced" category at this time.

*** More than 80 additional species of Stelis are being described in the next volume of Luer's Icones Pleurothallidinarum, Stelis of Bolivia, which is in press. Those are not included in this species count at this time.

in different lineages of the subtribe. It is to be expected that in such a large and diverse group, single characters are not completely unique; nevertheless that does not mean they are uninformative, especially when used in combination. This is especially the case for groups of species that under specific pollinator pressure have evolved having similar floral morphology even though they are not phylogenetically related. Luer (1986a) noted that plant morphology, which is not under such pressure, can be a better indicator of common evolutionary history. Nonetheless, plant morphology can also be under selective pressure due to particular ecological conditions, and cannot therefore be used by itself either. Aside from understanding if characters are phylogenetically informative or not, whether a particular state is ancestral or derived has traditionally been one of the most difficult to determine. Luer (1986a) could not with certainty determine whether eight pollinia or two pollinia is the most ancestral state in Pleurothallinae. DNA-based phylogenies have helped in establishing not only how many times certain morphological features have appeared but also the polarity of their states.

There are nine major clades within the Pleurothallidinae (Fig. 2). For ease of discussion, all generic and subgeneric groupings within the subtribe are grouped by their affinity to one of the genera within each of those clades. The proposed affinities are Acianthera (Ac), Dilomilis (Di), Lepanthes (Le), Masdevallia (Ma), Octomeria (Oc), Phloeophila (Ph), Pleurothallis $(\mathrm{Pl})$, Restrepia $(\mathrm{Re})$ and Specklinia (Sp); the oldest generic name is used here for the species within those clades (except Pleurothallis). This phylogenetic arrangement of the subtribe, despite taking only DNAbased studies into consideration (Pridgeon et al. 2001, Stenzel 2004, Solano-Gómez 2005, Matuszkiewicz \& Tukallo 2006, Abele 2007, Forster 2007, Meyer \& Cameron 2009, Karremans 2010, 2014, Endara 2011, Bogarín et al. 2013, Chiron et al. 2012, Karremans et al. 2013a, 2013b, Wilson et al. 2013, in press, Pessoa et al. 2014, Karremans \& Rincón-González 2015, McDaniel \& Cameron 2015, Chiron et al. 2016), has 


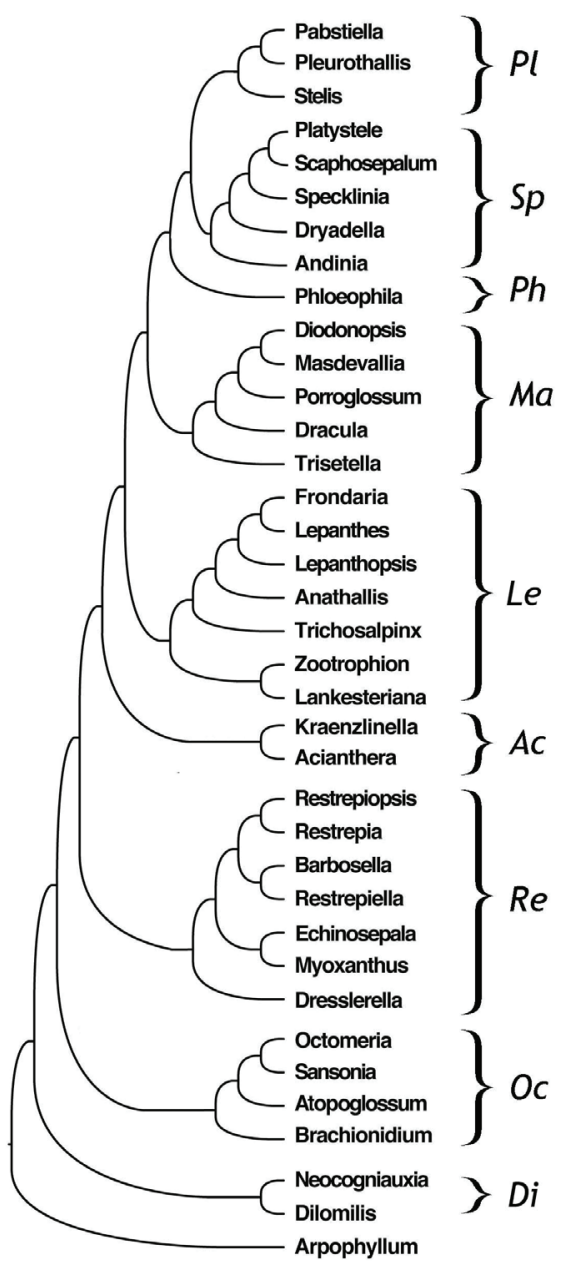

FIGURE 2. Phylogenetic overview of the main affinities within the Pleurothallidinae based on the available DNA based studies.

striking similarities with that proposed by Luer (1986c) on the basis of morphology (Fig. 3). Nevertheless, it is important to note at this point that convergence in basically all morphological traits that have been given phylogenetic importance are known to occur in the subtribe. The phylogenetic inference proposed by Neyland et al. (1995) based mostly on anatomical characters of the leaf, stem, and root is extremely different from that presented by Stenzel (2000) based on pollen morphology; both differ substantially from Luer (1986c), which was based mostly on anther position, lateral sepal fusion, and presence or absence of an annulus. None of them reflects the DNA-based phylogenetic inferences faithfully.

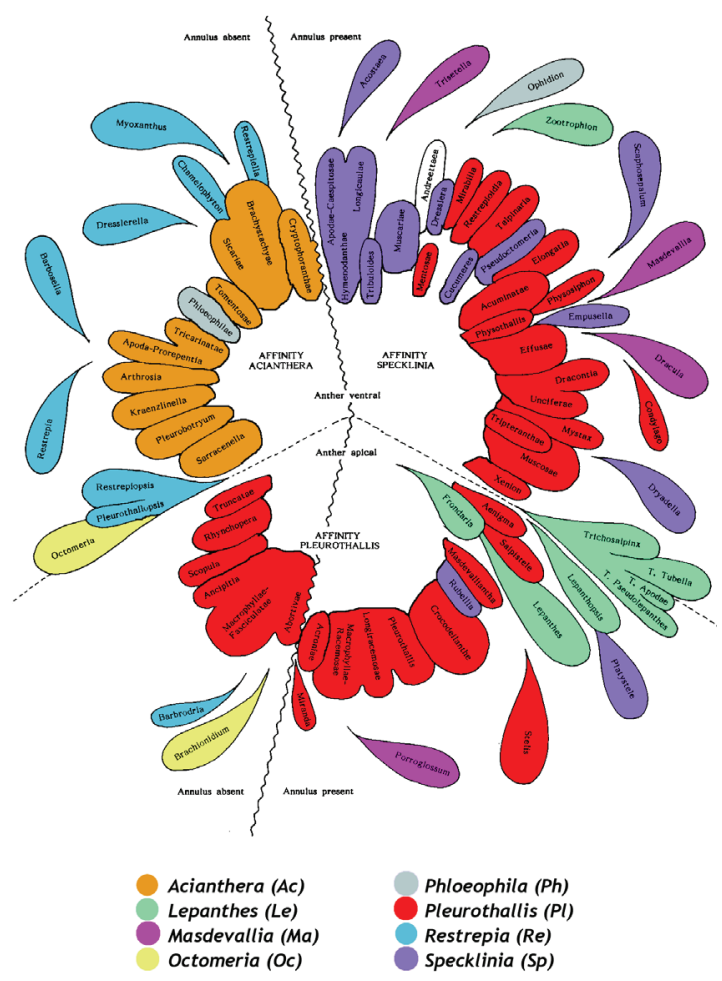

FIgURE 3. The affinities within the Pleurothallidinae proposed here superimposed on the morphologically based phylogenetic inference of the subtribe proposed by Luer (1986c).

\section{Affinity Acianthera}

Several generic names have been proposed within this group, most quite recently. However, only Acianthera (Fig. 4) and Kraenzlinella currently receive broad acceptance as distinct genera. Both genera, although proposed more than a century ago, were not commonly used until recently when they were re-established on the basis of the DNA analyses published by Pridgeon et al. (2001). DNA data made available of additional species of both genera, as well as of other species of Pleurothallis (from which they were segregated), show that they are still in need of redefinition. If Acianthera is to be maintained in its currently most accepted, broad sense (Pridgeon 2005), then it includes the generic concepts of Arthrosia, Brenesia, Cryptophoranthus, and Sarracenella, as proposed by Pridgeon \& Chase (2001) and Chiron $\&$ van den Berg (2012). Nevertheless, it should also include Aberrantia, as suggested by Luer (2004) and 


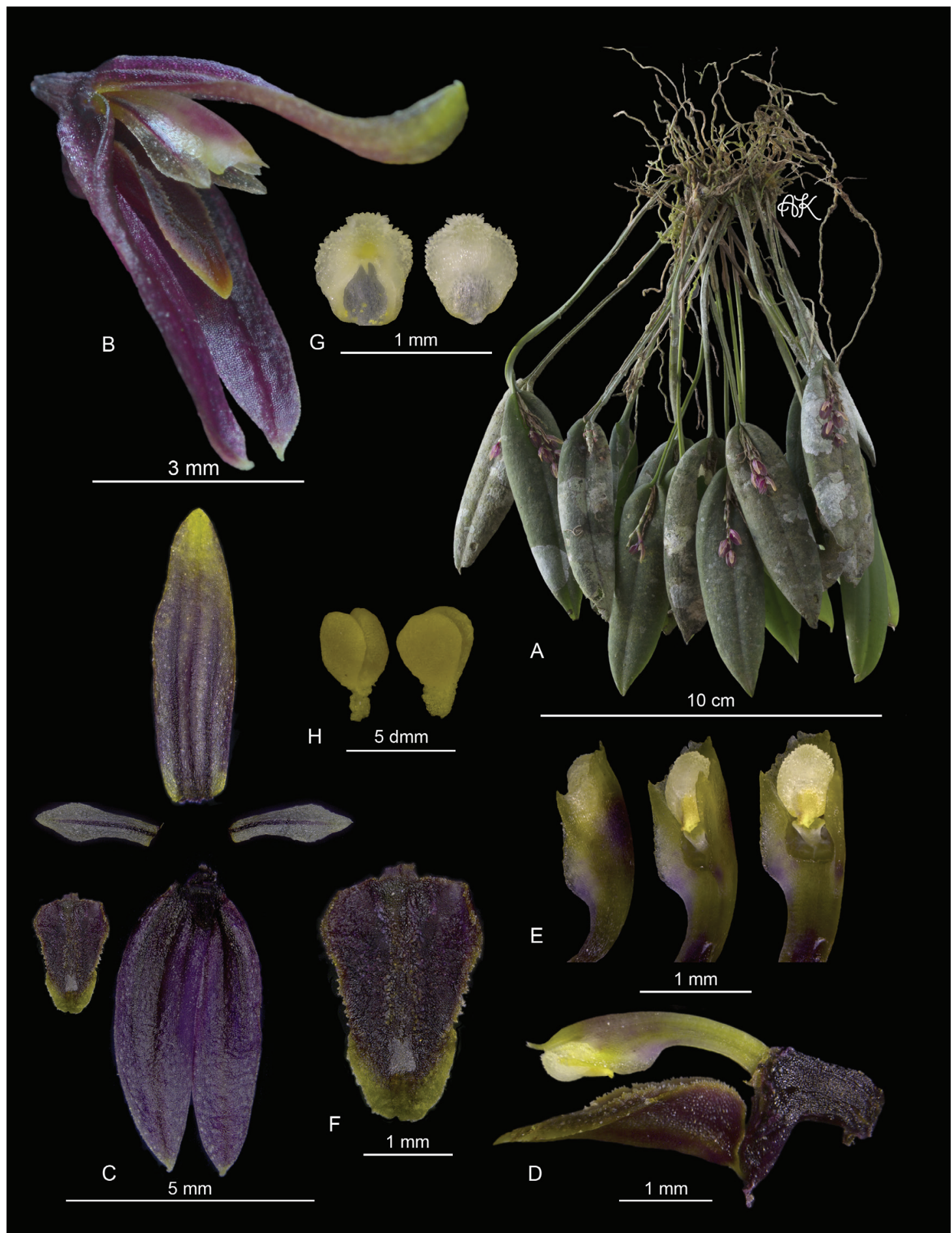

FIgURE 4. Lankester Composite Dissection Plate (LCDP) of Acianthera lojae (Schltr.) Luer. A. Habit. B. Flower. C. Dissected perianth. D. Column and lip, lateral view. E. Column in ventral and lateral views. F. Lip G. Anther cap. H. Pollinia. Photographs by Andrea Morales Morales and A. Karremans based on Karremans 6548 (JBL-spirit). 
proposed by Bogarín et al. (2008), Antilla, as shown by Stenzel (2004), Apoda-prorepentia, as shown by Stenzel (2004) and Karremans \& Rincón-González (2015), Didactylus, as suggested by Luer (2004), Ogygia, as proposed by Solano-Gómez $(2003 ; 2015)$, Pleurobotryum, as shown by Chiron et al. (2012), Proctoria, as suggested by Luer (2006), and Unguella, as suggested by Luer (2004). To my knowledge, there are no DNA data available (published or unpublished) of species belonging to the monospecific genera Ogygia and Proctoria that can confirm their exact phylogenetic relationships. However, the first is similar to other Acianthera species found in Mexico and Guatemala and the second is reminiscent of Antilla species, as was also noted by Stenzel (2007), and as such it would belong in Acianthera s.l.

Kraenzlinella, as previously mentioned, has lately received recognition as a distinct genus (Pridgeon 2005). In the molecular phylogeny of Pleurothallidinae published in Pridgeon et al. (2001), the single Kraenzlinella sequence was found sister to Brachionidium, and not particularly closely related to the other Acianthera species. Nevertheless, the availability of additional sequences from diverse Acianthera species (Stenzel 2004, Chiron et al. 2012, Karremans \& Rincón-González 2015) and also from diverse Kraenzlinella species now places the genus close to Acianthera. This is expected, and was indeed mentioned by Luer (1994), based on morphological similarity; Brachionidium is quite different. In fact, it is likely that the relatively long branches of the representatives of both Kraenzlinella and Brachionidium had initially misplaced the two genera in Pridgeon et al. (2001), as neither is related to Myoxanthus as was found. Kraenzlinella is for now accepted as it was defined by Pridgeon (2005) until more evidence is available, but it is likely that it will need to be either redefined or included within a broader concept of Acianthera.

Finally, genus Dondodia Luer was proposed on the basis of Cryptophoranthus erosus Garay, an unusual species known only from Hispaniola. It had been placed in Pleurothallis subgen. Acianthera sect. Cryptophoranthae Luer (1986c) on account of the connation of the dorsal sepal with the lateral synsepal. The species of that section would later be found embedded within Acianthera (Pridgeon et al.
2001) and transferred to the genus (Pridgeon and Chase 2001), where they were later given subgeneric recognition as Acianthera sect. Cryptophoranthae (Luer) Chiron \& van den Berg. Even though it is likely that Dondodia erosa (Garay) Luer does belong in the Acianthera affinity, it is unclear where it is placed. It is perhaps related to species in the Antillean genera Antilla and Proctoria.

\section{Affinity Dilomilis}

This affinity is made up of only three genera, Dilomilis Raf., Neocogniauxia Schltr. and Tomzanonia Nir, of which eight species are known. They have been mostly associated with Laeliinae until they were found sister to Pleurothallidinae in the DNAbased phylogeny presented by Pridgeon et al. (2001). Thereafter, Dilomilis, Neocogniauxia, and Tomzanonia have been treated as members of Pleurothallidinae by Pridgeon (2005). It is clear, nevertheless, that they are at best aberrant among the pleurothallids, and the fact is that the same DNA data would also justify their placement as a sister subtribe alongside rather than within Pleurothallidinae.

It is important to note that when describing genus Dilomilis, Rafinesque described and selected as type a species with the name D. serrata Raf. Diverse authors have ascribed that name solely to Rafinesque as if the author were proposing it as a new species. Nevertheless, Rafinesque's intention was clearly to transfer Octomeria serratifolia Hook. to Dilomilis as he specifically cited Hooker's original publication and literally transcribed the original Latin description and collection data. The name was simply misspelled, a misspelling that is to be corrected and does not render his combination in Dilomilis invalid. Therefore, that name should correctly be cited as Dilomilis serratifolia (Hook.) Raf., and as a consequence the genus Octadesmia is illegitimate because it based on the same type species as Dilomilis.

The exclusion of the genera in the Dilomilis affinity from Pleurothallidinae, as Borba et al. (2011) pointed out, allows for a better characterization of the latter. Traditional diagnostic morphological synapomorphies for Pleurothallidinae such as 1) presence of a stem transformed into a monophyllous ramicaul, and 2) an articulation between the pedicel and ovary, together with biological synapomorphies, including 3) auto- 
incompatibility and 4) myophily (fly pollination), are lost with the inclusion of species of Dilomilis, Neocogniauxia, and Tomzanonia. Nevertheless, DNA data clearly show that they are closer to Pleurothallidinae than to any other subtribe.

\section{Affinity Lepanthes}

Eight genera make up this affinity: Anathallis Barb.Rodr., Draconanthes (Luer) Luer, Frondaria Schltr., Lankesteriana Karremans, Lepanthes Sw., Lepanthopsis (Cogn.) Ames, Trichosalpinx Luer, and Zootrophion Luer. Of these, only Lepanthes and Lepanthopsis received generalized recognition in botanical literature before Luer's monographic works on Pleurothallidinae. In addition to accepting the former, Luer proposed Frondaria, Trichosalpinx and Zootrophion in the 1980s, and Draconanthes in the 1990s. They received recognition by other authors as well and were retained as such by Pridgeon and Chase (2001) and Pridgeon (2005). Anathallis, which had traditionally been considered a synonym of Pleurothallis, would be re-considered on the basis of DNA evidence presented by Pridgeon et al. (2001). Anathallis as defined then was latter shown to include a group of species more closely related to some Trichosalpinx (Chiron et al. 2012; Karremans 2014), for which genus Lankesteriana was proposed, and a group of species belonging to Stelis s.l. (Chiron et al. 2012; Karremans et al. 2013a). The exclusion of those taxa from Anathallis rendered it monophyletic (Karremans 2014).

After the DNA-based redefinition of Pleurothallidinae, three more genera belonging to the Lepanthes affinity would be proposed on morphological grounds: Epibator Luer, Expedicula Luer, and Panmorphia Luer. In general terms they received little acceptance. Epibator was segregated from Zootrophion, and in fact DNA data showed that Epibator species form a monophyletic group sister to the other species of Zootrophion. Nevertheless, genetic distance is low. Expedicula was proposed to segregate two species previously placed in Lepanthopsis. Unpublished DNA data found Expedicula species embedded within the latter, it cannot therefore be recognized without rendering Lepanthopsis polyphyletic. Panmorphia, as the name suggests, was conceived as polyphyletic. Luer (2009) himself would note that many of its species graded into Anathallis and would place it in synonymy. DNA data showed that indeed the type species of Panmorphia, Anathallis sertularioides (Sw.) Pridgeon \& M.W.Chase, is a close relative of the type of Anathallis, Anathallis obovata (Lindl.) Pridgeon \& M.W.Chase (Stenzel 2004, Chiron et al. 2012, Karremans 2014).

Trichosalpinx is a special case in Pleurothallidinae because it is clearly non-monophyletic, but there seems to be no way to resolve the issue at this time. Luer's 1997 monograph of Trichosalpinx already suggested that the genus was artificial as it was made up basically of any pleurothallid species with lepanthiform bracts that did not fit the criteria of Draconanthes, Lepanthes or Lepanthopsis. In both Pridgeon et al. (2001) and Karremans (2014), Trichosalpinx was found polyphyletic, but no proposals to re-circumscribe it were made. Unpublished DNA data from three out of the four subgenera proposed by Luer (1997) indicate that Trichosalpinx contains at the very least seven unrelated clades, and that they are diversely interrelated to all of the other accepted genera in this affinity. Therefore, Trichosalpinx will certainly need to be dismembered and its species either assigned to broader concepts of currently accepted genera and/or to novel generic concepts.

\section{Affinity Masdevallia}

Five genera belonging to this affinity have been recognized with some consistency in the last few years: Diodonopsis Pridgeon \& M.W.Chase, Dracula Luer, Masdevallia Ruiz \& Pav. (Fig. 5), Porroglossum Schltr. and Trisetella Luer. Masdevallia was proposed in the 18th century, and it was not until the beginning of the 20th century that the first group of species would be segregated from it under the generic name Porroglossum. In the second half of the 20th century, Luer proposed the segregation of three more species groups from Masdevallia under the generic names Dracula, Dryadella Luer (which does not belong to this affinity), and Trisetella. The five genera would be recognized and kept separate from Masdevallia in the following works (Luer 1986a, 1986b), and all of them would receive support as distinct, monophyletic genera in the molecular phylogeny published by Pridgeon et al. (2001). From this point on the story becomes much more complex. 


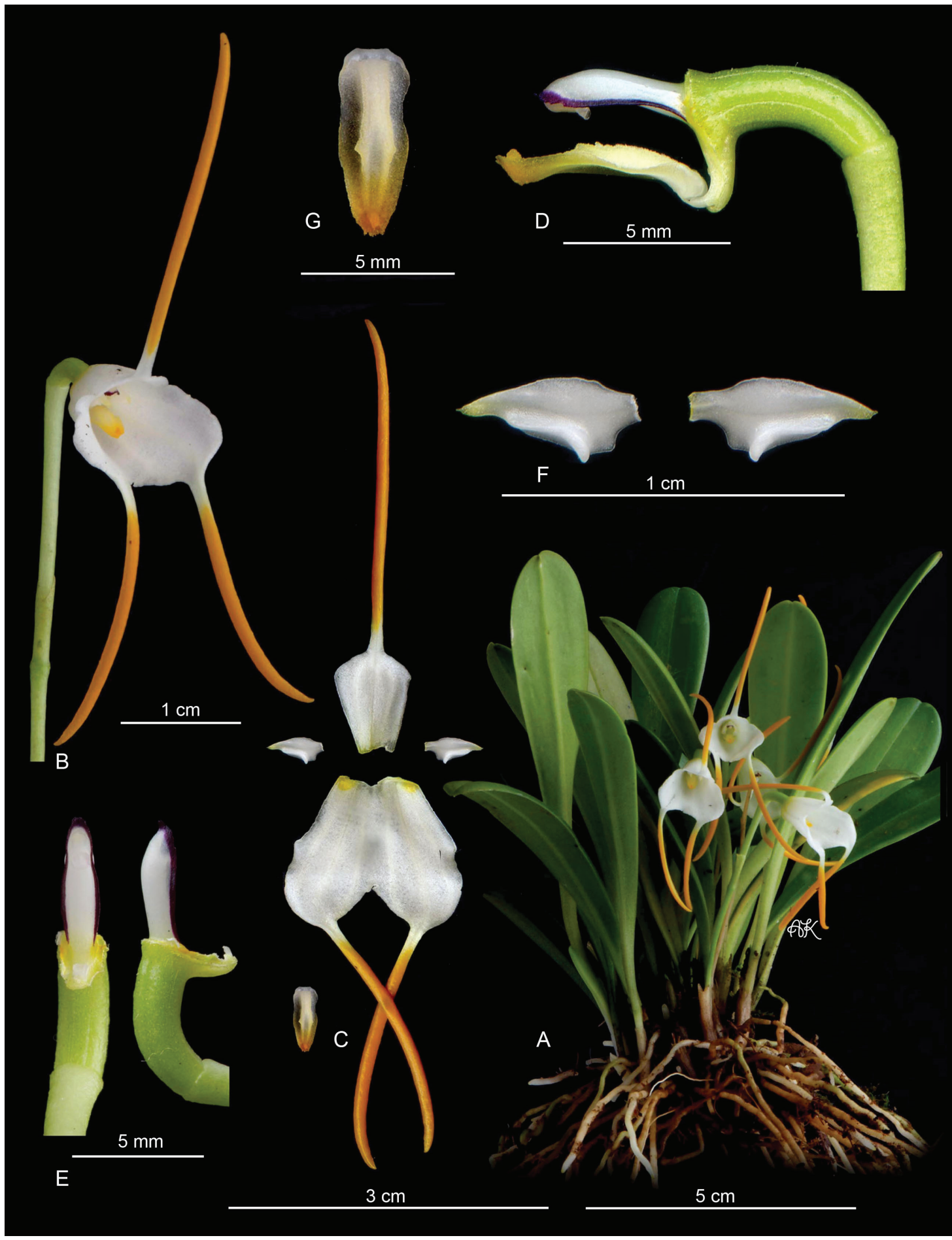

Figure 5. Lankester Composite Dissection Plate (LCDP) of Masdevallia laucheana J.Fraser. A. Habit. B. Flower. C. Dissected perianth. D. Column and lip, lateral view. E. Column in ventral and lateral view. F. Petals. G. Lip. Photographs by A. Karremans based on Karremans 5901 (JBL-spirit). 
Pridgeon and Chase (2001) proposed genus Diodonopsis for what was previously Masdevallia sect. Pygmaeae (Luer 1986b), based on the solitary placement of the accession of the single species of this group included in their molecular phylogeny (Pridgeon et al. 2001). Prior to the proposal, Luer (2000b) had suggested that the species belonging to his Masdevallia subgen. Pygmaeia "probably are not closely related," and doubted the monophyly of Diodonopsis, pointing out that the type species had not been analyzed (Luer 2002b). In fact, later DNA studies that included more samples of Diodonopsis and Masdevallia (Matuszkiewicz \& Tukallo 2006, Abele 2007) proved that indeed the former is not monophyletic as currently defined. Nevertheless, it does appear that $D$. erinacea (Rchb.f.) Pridgeon \& M.W.Chase, the single species originally analyzed, and D. pygmaea (Kraenzl.) Pridgeon \& M.W.Chase, the type species of the genus, are sister to each other. What is not yet clear is how many other species actually belong in Diodonopsis and if the genus is truly distinct from Masdevallia.

Luer would not leave the matter at that and a few years later proposed additional segregate genera from Masdevallia: Acinopetala Luer, Alaticaulia Luer, Buccella Luer, Byrsella Luer, Fissia, Jostia Luer, Luzama Luer, Megema Luer, Petalodon Luer, Regalia Luer, Reichantha Luer, Spectaculum Luer, Spilotantha Luer, Streptoura Luer, Triotosiphon Schltr. ex Luer, and Zahleria Luer, as well as the recognition of the previously proposed Jostia Luer, Portillia Königer and Rodrigoa Braas (Luer 2006). The proposals received little acceptance from other authors because of the lack of accompanying evidence. In fact, the available DNA data show that most of these ill-defined genera are indeed artificial as currently circumscribed (Pridgeon et al. 2001, Matuszkiewicz \& Tukallo 2006, Abele 2007).

\section{Affinity Octomeria}

Affinity Octomeria as defined here is made up of four genera, Atopoglossum Luer, Brachionidium Lindl., Octomeria R.Br. (Fig. 6) and Sansonia Chiron. Octomeria, proposed early in the 19th century to accommodate pleurothallid species with eight pollinia, has remained virtually unchanged since it was published. The same can be said for Brachionidium, a genus of species with 6 or 8 pollinia and mostly recognized as a distinct genus since it was proposed in 1859. Atopoglossum, published in 2004, was established for a few Cuban endemic species with an abbreviated ramicaul, a three-lobed lip, an elongate column, and eight pollinia. Sansonia, published in 2012, was named on the basis of the lone placement of Pleurothallis neobradei Luer and an unnamed Acianthera species in a DNA-based phylogenetic analyses of Brazilian pleurothallids.

The phylogenetic study of Pleurothallidinae based on DNA data (Pridgeon et al. 2001) showed Octomeria in a basal position in the subtribe. That in fact made sense considering that the morphological features of Octomeria, elongate stems and multiple pollinia, are somewhat reminiscent of Dilomilis and Neocogniauxia, the sistergenera of the Pleurothallidinae. Brachionidium however, was found sister to Kraenzlinella, in a clade that was sister to Myoxanthus. Morphologically it makes little sense that Brachionidium, Kraenzlinella and Myoxanthus are close relatives; in fact here they are treated in three different affinities. DNA-based phylogenetic analyses by Stenzel (2004) and Forster (2007) place Brachionidium in a clade together with Atopoglossum and Octomeria. My own analyses also place Brachionidium sister to those same genera. It is worth mentioning that the sequences of Brachionidium species include many unique changes (indels) which make them difficult to align and which results in them having extraordinarily long branches. That makes them difficult to place with complete certainty. Nevertheless, the placement of Brachionidium close to Atopoglossum and Octomeria, rather than Kraenzlinella and Myoxanthus, is much more likely based on morphology, but this remains to be confirmed. The species of all three genera have 6 or 8 pollinia.

The two species of Sansonia were found to be sister to all Pleurothallidinae when using Octomeria as outgroup (Chiron et al. 2012). However, by selecting Octomeria as an outgroup in their analyses the authors cannot actually place Sansonia with confidence (because the underlying assumption that the ingroup is monophyletic would not be met). Unpublished DNA-based phylogenetic analyses place the Sansonia sequences sister to other Octomeria sequences (Karremans, in prep.). Sansonia species are creeping plants with short ramicauls and tubular flowers with a synsepal and two pollinia, characteristics that are 


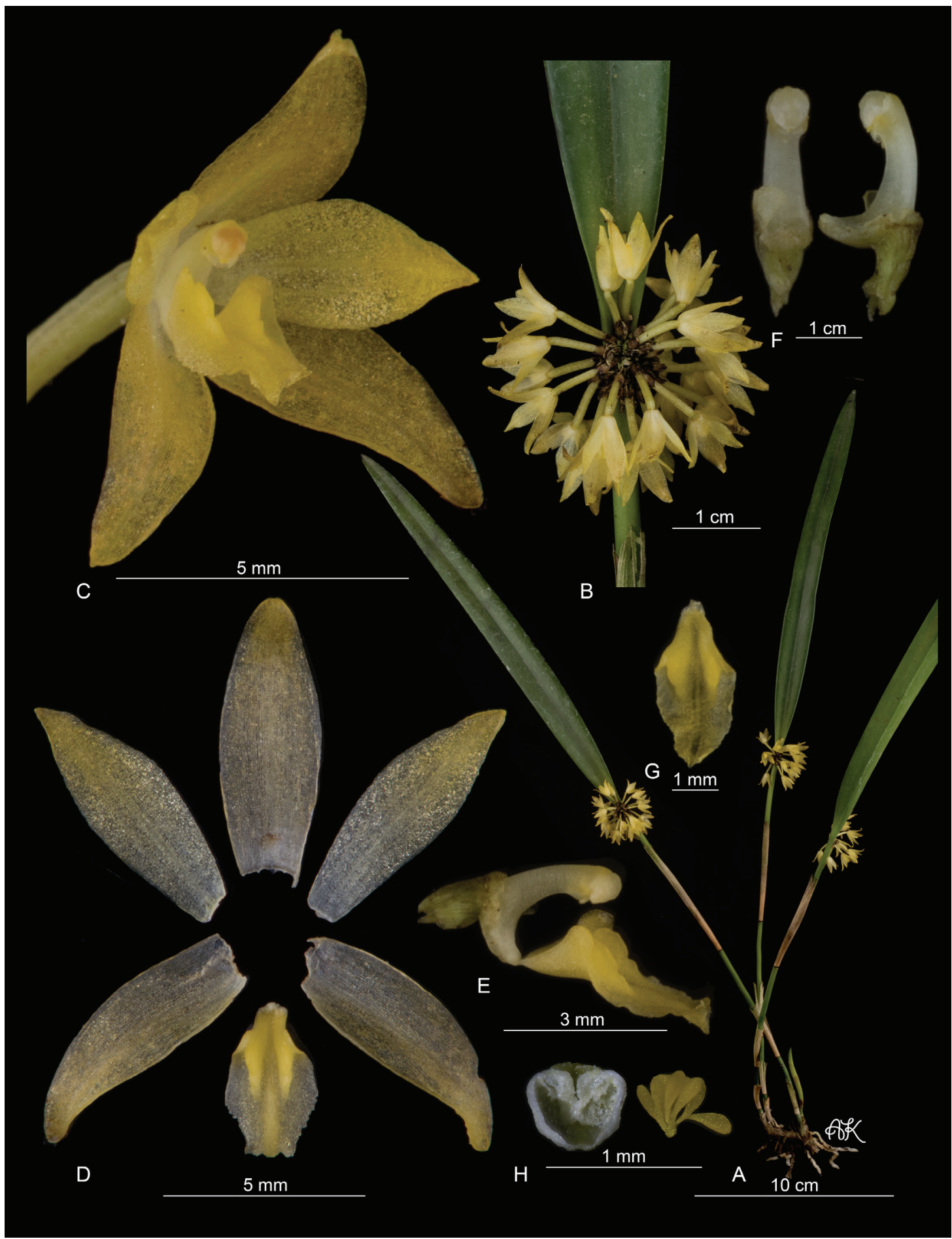

Figure 6. Lankester Composite Dissection Plate (LCDP) of Octomeria valerioi Ames \& C.Schweinf. A. Habit. B. Inflorescence. C. Flower. D. Dissected perianth. E. Column and lip, lateral view. F. Column in ventral and lateral view. G. Flattened lip. H. Pollinia and anther cap. Photographs by A. Karremans based on Bogarin 3017 (JBL-spirit). 
generally found in derived groups of Pleurothallidinae. The genus is clearly different from Pleurothallis and Octomeria; nevertheless it is important to obtain DNA data from additional specimens of this genus to confirm its position.

\section{Affinity Phloeophila}

Genus Phloeophila Hoehne \& Schltr. is the oldest name applicable to this group of species. It was recently reconsidered by Pridgeon and Chase (2001) on the basis of the molecular phylogeny published by Pridgeon et al. (2001). The study showed that the species of Phloeophila (in a strict sense) formed a unique clade together with species previously placed in Luerella Braas and Ophidion Luer and not closely related to Pleurothallis. The three genera were combined into a broadly circumscribed Phloeophila even though the species of all three had little morphological common ground. In a phylogenetic analysis of Brazilian Pleurothallidinae, Chiron et al. (2012) found accessions labeled Phloeophila nummularia (Rchb.f.) Garay, the type species of Phloeophila, embedded within Pabstiella. Nevertheless, this is a mistake that has been rectified (Chiron et al. 2016). In an independent analysis, Stenzel (2004) found Cuban accessions of $P$. nummularia to group with the other Phloeophila species as expected.

Morphologically, Phloeophila s.l. species are virtually undiagnosable. In fact, one knows that a species belongs to Phloeophila s.l. basically because it can be assigned on morphological grounds to either Luerella, Ophidion or Phloeophila s.s. From published and unpublished DNA data it is clear that even though species of all three genera form a single clade, each of them could also be monophyletic on their own. In fact, the DNA evidence also gives an explanation for the highly dissimilar morphologies as each of the three clades lies on long, highly divergent branches. The only reason this Phloeophila in its broad circumscription has remained a single genus is probably species number. If split up, Luerella would be monospecific, Ophidion would have six species, and Phloeophila s.s. only two. Phloeophila s.l. has nine species at this time (Chiron et al. 2016). Without doubt, if each genus had dozens or hundreds of species they would have been kept separate.

\section{Affinity Pleurothallis}

Three genera with different taxonomic histories belong within this affinity: Pabstiella Brieger \& Senghas (Fig. 7), Pleurothallis R.Br. (Fig. 8), and Stelis Sw.; each of them is discussed separately.

In the DNA-based phylogenetic analysis of Pleurothallidiane by Pridgeon et al. (2001), Pleurothallis mentosa Cogn., P. mirabilis Schltr. and $P$. tripterantha Rchb.f. were found to form an isolated clade sister to Pleurothallis and Stelis. The authors published genus Anthereon Pridgeon \& M.W.Chase to give generic recognition to the particular clade. However, the name is superfluous (and illegitimate) because Pabstiella had already been proposed for one of those species, P. mirabilis. Gyalanthos Szlach. \& Marg., published almost simultaneously, was also based on P. mirabilis, and therefore it too is illegitimate. Only a handful of species were initially assigned to Pabstiella (Pridgeon 2005), but several dozen more species have since been recognized as belonging to the genus (Luer 2006, 2007), especially Brazilian species mistakenly believed to belong in Specklinia and Stelis s.l. The genus Ronaldella Luer was proposed to accommodate Pleurothallis aryter Luer and P. determannii Luer; DNA data placed them within Pabstiella (Karremans et al. 2013a).

Pleurothallis at some time or another included the species from the vast majority of other genera in this subtribe; notable exceptions are Lepanthes, Masdevallia, Stelis, and Octomeria. Luer (1986c) published a comprehensive subgeneric classification of Pleurothallis. Pridgeon and Chase (2001) clearly demonstrated the polyphyly of the genus and proposed a narrower circumscription of Pleurothallis by recognizing or broadening the genera Acianthera, Anathallis, Andinia, Pabstiella, Phloeophila, Specklinia, and Stelis. Luer (2004, 2006, 2007) followed with an even narrower concept of Pleurothallis by segregating the genera Ancipitia (Luer) Luer, Elongatia (Luer) Luer, Lindleyalis Luer, Loddigesia Luer (= Lalexia Luer), Mixis Luer, Orbis Luer, and Tigivesta Luer, while recognizing the previously proposed Acronia C.Presl, Colombiana Ospina, Rhynchopera Klotzsch and Talpinaria H.Karst. The recognition of these genera reduces Pleurothallis s.s. to less than a couple of hundred species, and the proposal has found little support by other authors. 


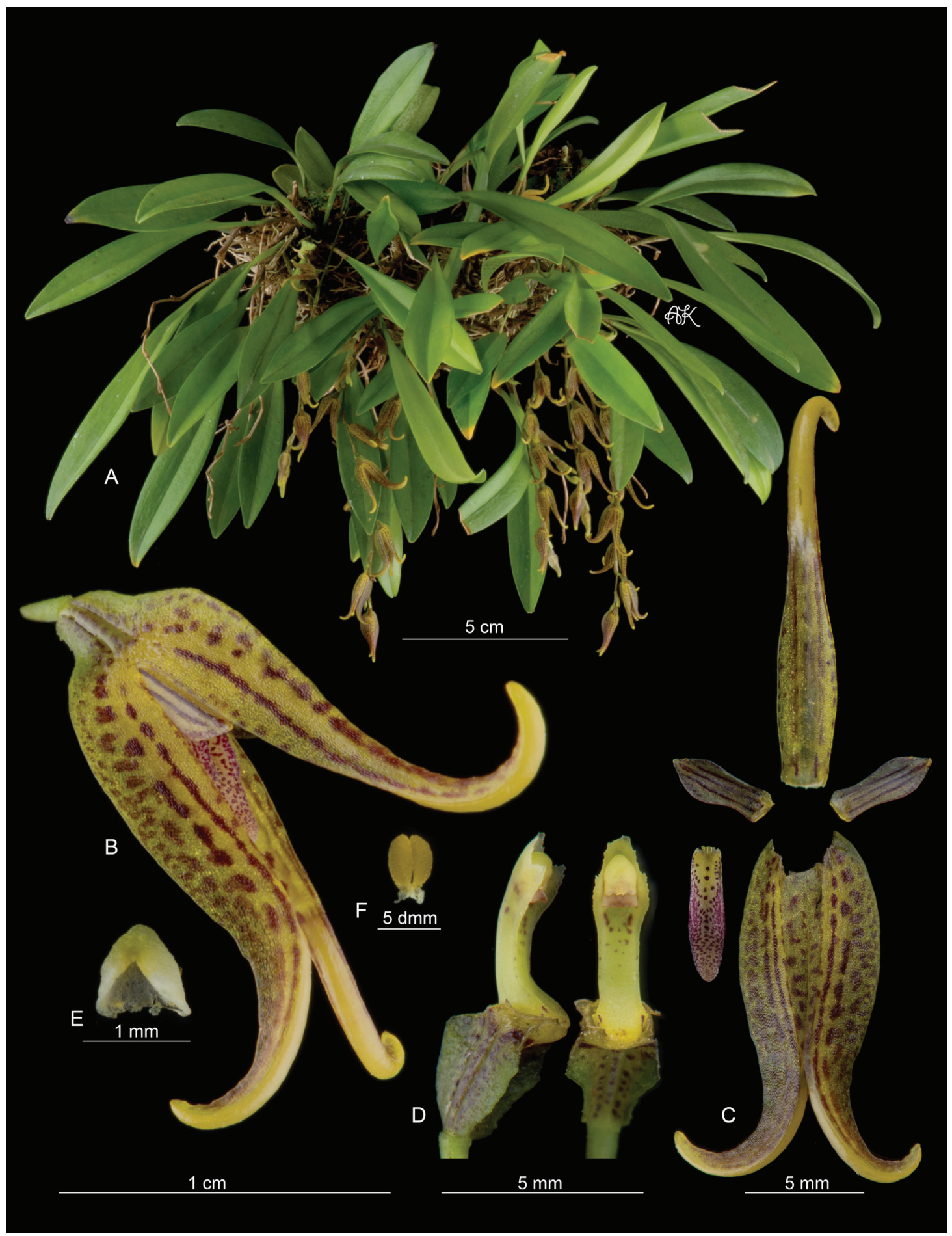

Figure 7. Lankester Composite Dissection Plate (LCDP) of Pabstiella tripterantha (Rchb.f.) F.Barros. A. Habit. B. Flower. C. Dissected perianth. D. Column in ventral and lateral view. E. Anther cap. F. Pollinarium. Photographs by A. Karremans and Jazmín Alomía based on Bogarín 5512 (JBL-spirit). 


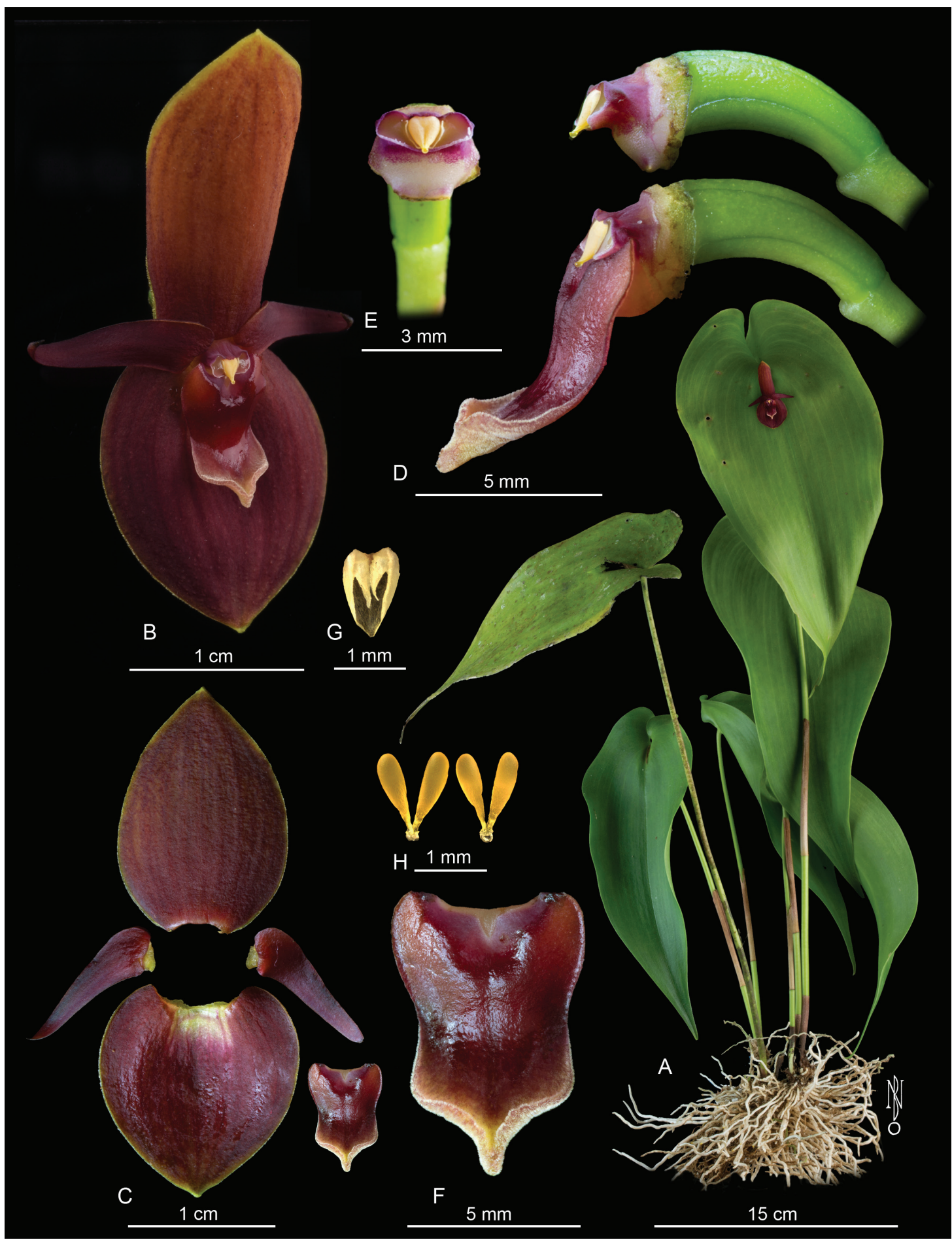

FIGURE 8. Lankester Composite Dissection Plate (LCDP) of Pleurothallis cardiothallis Rchb.f. A. Habit. B. Flower. C. Dissected perianth. D. Column and lip, lateral view. E. Column in ventral view. F. Lip. G. Anther cap. H. Pollinaria. Photographs by Noelia Belfort Oconitrillo and A. Karremans based on Karremans 6580 (JBL-spirit). 
Morphologically, the lines that separate Ancipitia from Colombiana, and Acronia from Pleurothallis s.s., are blurred, and Elongatia is undiagnosable. The nonmonophyly of these genera is supported by published and unpublished DNA data (Karremans et al. 2013a, Wilson et al. 2013). Even though some of the other genera may indeed represent natural groups, the morphological features used to distinguish them are too plastic, and genetic distance seems to be low as well.

Species of Stelis had been traditionally easy to distinguish from species of other genera, and the genus had, until relatively recently, not been subjected to major taxonomic changes with the exception of a reduction proposed by Garay (1979). Pridgeon et al. (2001) proposed a broader circumscription of Stelis with the inclusion of several subgenera of Pleurothallis [i.e., Crocodeilanthe (Rchb.f. \& Warsz.) Luer, Dracontia Luer, Effusia Luer, Elongatia Luer, Mystax Luer, Physosiphon (Lindl.) Luer, Physothallis (Garay) Luer, Pseudostelis (Schltr.) Luer, and Unciferia (Luer) Luer], as well as the smaller genera Condylago Luer and Salpistele Dressler. Luer (2002b) shed doubt on the accuracy of the DNA data and continued using the narrow circumscription of the genus (Luer 2009). Several authors would afterwards recognize some genera segregated from Stelis s.1., including Condylago, Crocodeilanthe, Dracontia, Effusiella, Elongatia, Lomax, Niphantha, Physosiphon, Physothallis and Unciferia, whereas other authors preferred to keep them within Pleurothallis.

The broader phylogenetic studies by SolanoGómez (2005) and Karremans et al. (2013a) clearly showed that species of the above mentioned genera are all indeed more closely related to Stelis s.s. than to Pleurothallis s.s. Their analyses also demonstrated that genera such as Effusiella and Elongatia (Luer) Luer are polyphyletic and cannot be recognized as currently defined, and that genera such as Crocodeilanthe, Dracontia, Physothallis, Salpistele and Unciferia, although natural groups, are paraphyletic and deeply embedded with Stelis s.1. It is clear that there are some well-defined clades within Stelis s.l. and that those could eventually be recognized as distinct genera; however, for the time being it is impossible to tell which species should be assigned to what clade with any confidence. It is more advisable to maintain a monophyletic Stelis s.l. rather than recognize several polyphyletic and paraphyletic small genera.

Finally, it is important to mention that the genera Elongatia and Lalexia Luer (=Loddigesia Luer, nom. illeg.) should definitely be excluded from the synonymy of Stelis as DNA data have amply proven that their type species, Pleurothallis restrepioides Lindl. and Pleurothallis quadrifida (Lex) Lindl., respectively, are closer to the Pleurothallis than to Stelis (Karremans et al. 2013a, Wilson et al. 2013).

\section{Affinity Restrepia}

The eight genera accepted in this affinity -Barbosella Schltr., Chamelophyton Garay, Dresslerella Luer, Echinosepala Pridgeon \& M.W.Chase, Myoxanthus Poepp. \& Endl. (Fig. 9), Pleurothallopsis Porto \& Brade, Restrepia Kunth and Restrepiella Garay $\&$ Dunst. --have undergone less drastic changes in the last few decades. With the exception of Echinosepala, they were recognized as distinct when the first molecular phylogeny of the pleurothallids by Pridgeon et al. (2001) was published (Luer 1986a). In fact, the changes suggested by the authors of this particular group of genera were relatively few. Basically three changes were made: 1) placing Barbrodia Luer, embedded within Barbosella in the analyses, under the synonymy of the latter; 2) reducing Restrepiopsis Luer under the synonymy of its sister genus Pleurothallopsis; 3) creating a new genus, Echinosepala, for a group of species previously assigned to Myoxanthus but not part of that clade. Unpublished DNA data from a broader set of species belonging to each of the genera mentioned confirm that as currently defined they are all monophyletic. Contrary to what was found by Pridgeon et al. (2001), Myoxanthus and Echinosepala are apparently sister genera. There would be little to gain by lumping the two genera as they are perfectly diagnosable and informative. To my knowledge, no DNA data (published or unpublished) is available of the monospecific genus Chamelophyton to confirm its exact phylogenetic relationships. However, based on the similar basal lobes of the lip, slender wing-less column and multiple pollinia, it seems to be related to species of Pleurothallopsis. The single species belonging to this genus is rarely found in Venezuela and Guayana. 


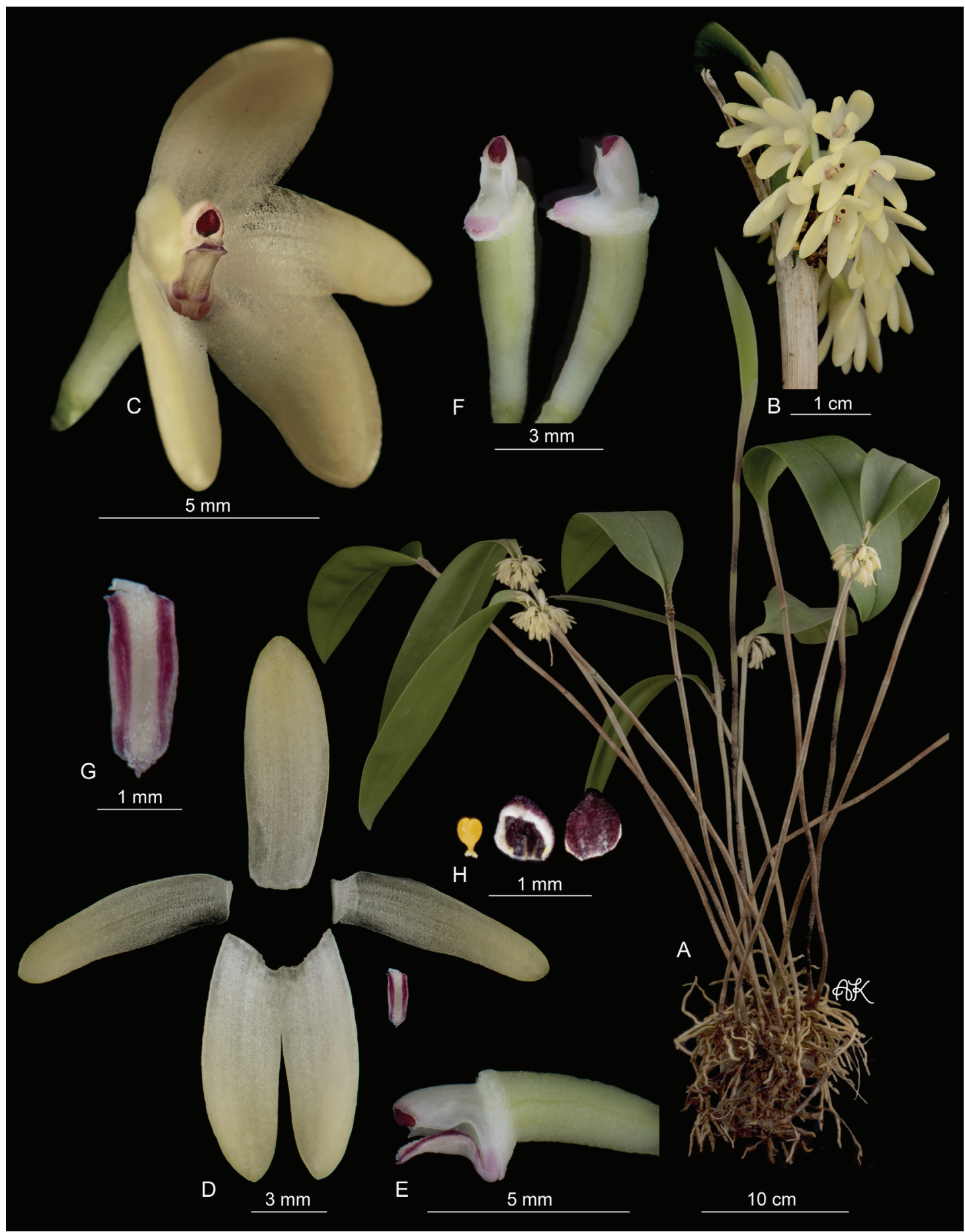

FIgure 9. Lankester Composite Dissection Plate (LCDP) of Myoxanthus octomeriae (Schltr.) Luer. A. Habit. B. Inflorescence. C. Flower. D. Dissected perianth. E. Column and lip, lateral view. F. Column in ventral and lateral view. G. Lip. H. Pollinia and anther cap. Photographs by A. Karremans and Gustavo Rojas Alvarado based on Karremans 5693 (JBLspirit). 


\section{Affinity Specklinia}

This affinity is currently made up of seven accepted genera: Andinia (Luer) Luer, Dryadella Luer, Muscarella Luer, Platystele Schltr. (Fig. 10), Scaphosepalum Pfitzer (Fig. 11), Specklinia Lindl., and Teagueia (Luer) Luer.

On one hand, Dryadella, Platystele, and Scaphosepalum were all treated as distinct, wellrecognized genera when Luer published his first monograph of Pleurothallidinae (Luer 1986a). The author would later segregate Teagueia from Platystele (1991), and the four genera would be generally accepted when Pridgeon et al. (2001) published their molecular phylogeny of Pleurothallidinae. On the other hand, the oldest generic name applicable to this affinity, Specklinia, had not been used for about 150 years, until it was "resurrected" from the synonymy of Pleurothallis by Pridgeon \& Chase (2001). DNA data clearly showed that Specklinia was sister to a clade composed of Platystele and Scaphosepalum; sister to all of them was Dryadella. Luer (2002b) did not recognize Specklinia initially but would later make many transfers expanding the circumscription of the genus (Luer 2004) and finally would reduce it to a handful of species by recognizing several new segregate genera (Luer 2006). The DNA data published by Pridgeon et al. (2001) showed that Acostaea Schltr., Pseudoctomeria Kraenzl., Empusella Luer, Muscarella Luer, Tribulago Luer, and Sarcinula Luer all belonged within their newly circumscribed Specklinia. A phylogenetic analysis including a broader sampling of Specklinia species confirmed the previous findings, but also places the genera Cucumeria Luer, Gerardoa Luer, and Sylphia Luer (on the basis of DNA data), and Areldia Luer and Tridelta Luer, (on the basis of morphology) within Specklinia (Karremans 2015, Karremans et al., in press).

The new study also shows that Muscarella Luer should be excluded from Specklinia if it is to be maintained as monophyletic, because Muscarella is sister to the clade that includes Platystele, Scaphosepalum, and Specklinia. It also places Incaea Luer (a genus previously believed to belong in Phloeophila) within Dryadella, whereas Rubellia (Luer) Luer, previously unplaced, is sister to Platystele. The latter relationships are supported by overall morphology and do seem reasonable. The position of Teagueia is not completely resolved. DNA data from a single accession places it in the Platystele-Scaphosepalum clade, but it is unclear to which genus it is most closely related. A broader sampling Teagueia species will allow for a better understanding of its relationships.

Finally, the concept of genus Andinia that is accepted here follows that which was proposed by Wilson et al. (in press). Many of its species had traditionally been placed in Lepanthes. The first step towards recognizing them as distinct was made by Luer (1986a), who transferred $L$. dielsii Mansf. and $L$. pensilis Schltr. to Salpistele Dressler. The two misfits were almost immediately given subgeneric recognition (Luer 1991), followed by generic status under the name Andina (Luer 2000a). Pridgeon and Chase (2001) broadened Andinia to include 10 species, the two from Salpistele together with several previously placed in Pleurothallis, on the basis of DNA data. Wilson et al. (in press) expanded Andinia even more on the basis of DNA data and morphological similarities. The authors showed that the Lepanthes nummularia Rchb.f. group, which had long been placed in Lepanthes, and was recently also given generic recognition under the illegitimate generic name Brachycladium (Luer) Luer and a few replacement genera, is phylogenetically allied to the species already placed in Andinia. Wilson et al. (in press) place Andinia in the Specklinia rather than the Pleurothallis clade where it has been found in other studies. The issue will undoubtedly need to be re-evaluated in the future with more data at hand.

\section{Uncertain affinities}

Andreettaea Luer, Selbyana 2: 183. 1978.

A single species of Andreettaea is known. It is apparently without close relatives. Luer (1986c) believed it to be allied with species of Pleurothallis subgen. Specklinia because of the abbreviated ramicaul. Nevertheless, we know now that this feature has appeared many times independently in Pleurothallidinae, and the species then assigned to $P$. subgen. Specklinia are now placed in many different genera. The non-resupinate flowers with fused sepals, acuminate petals, conspicuously lobbed lip, and pollinia with caudicles surely exclude it from genus Specklinia. It might belong in the Phloeophila affinity. DNA data will probably be needed to place Andreettaea among its relatives; it is clearly not a synonym of Pleurothallis 


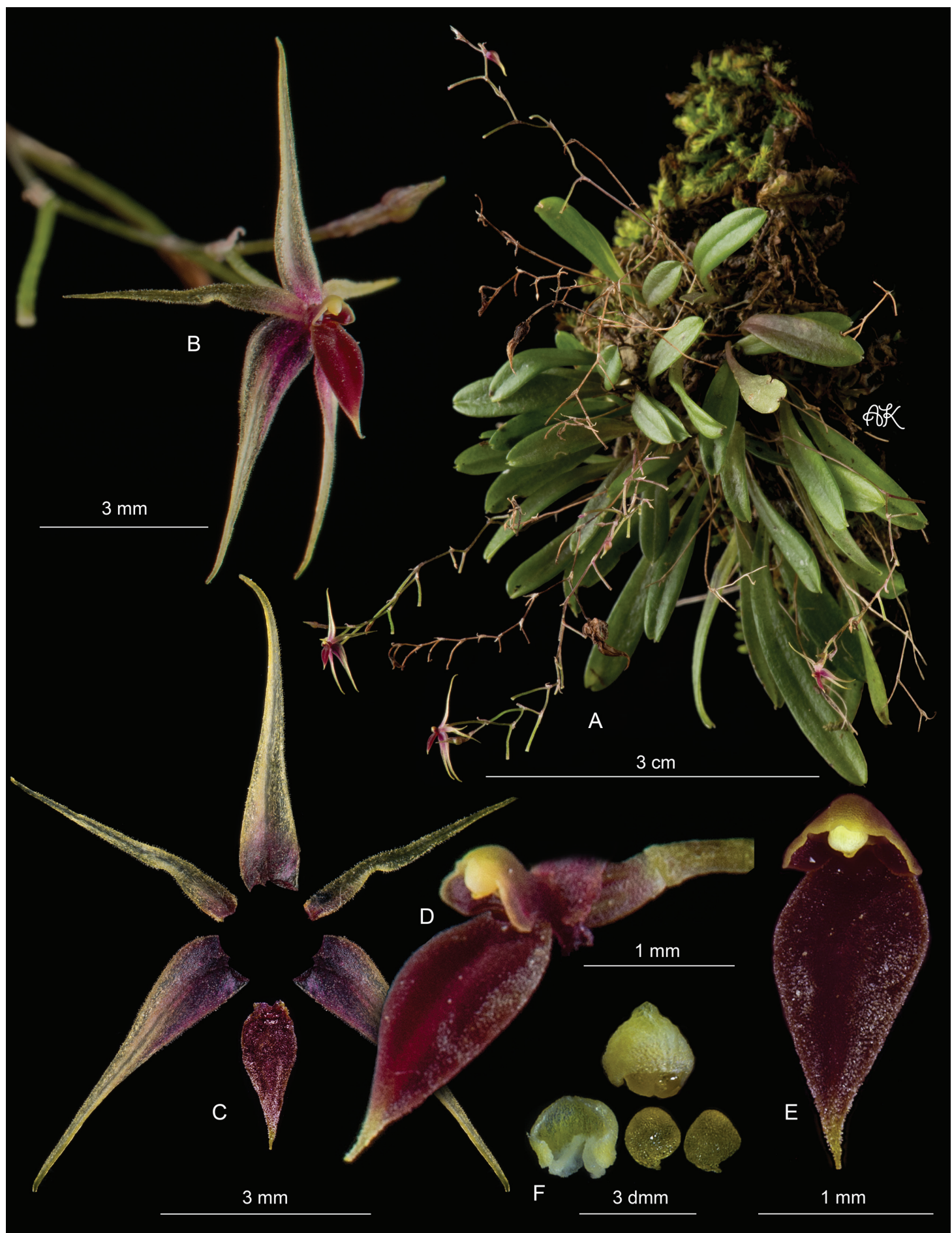

Figure 10. Lankester Composite Dissection Plate (LCDP) of Platystele oxyglossa (Schltr.) Garay. A. Habit. B. Flower. C. Dissected perianth. D. Column and lip, lateral view. E. Column and lip in frontal view. F. Pollinia and anther cap. Photographs by A. Karremans based on Karremans 7074 (JBL-spirit). 


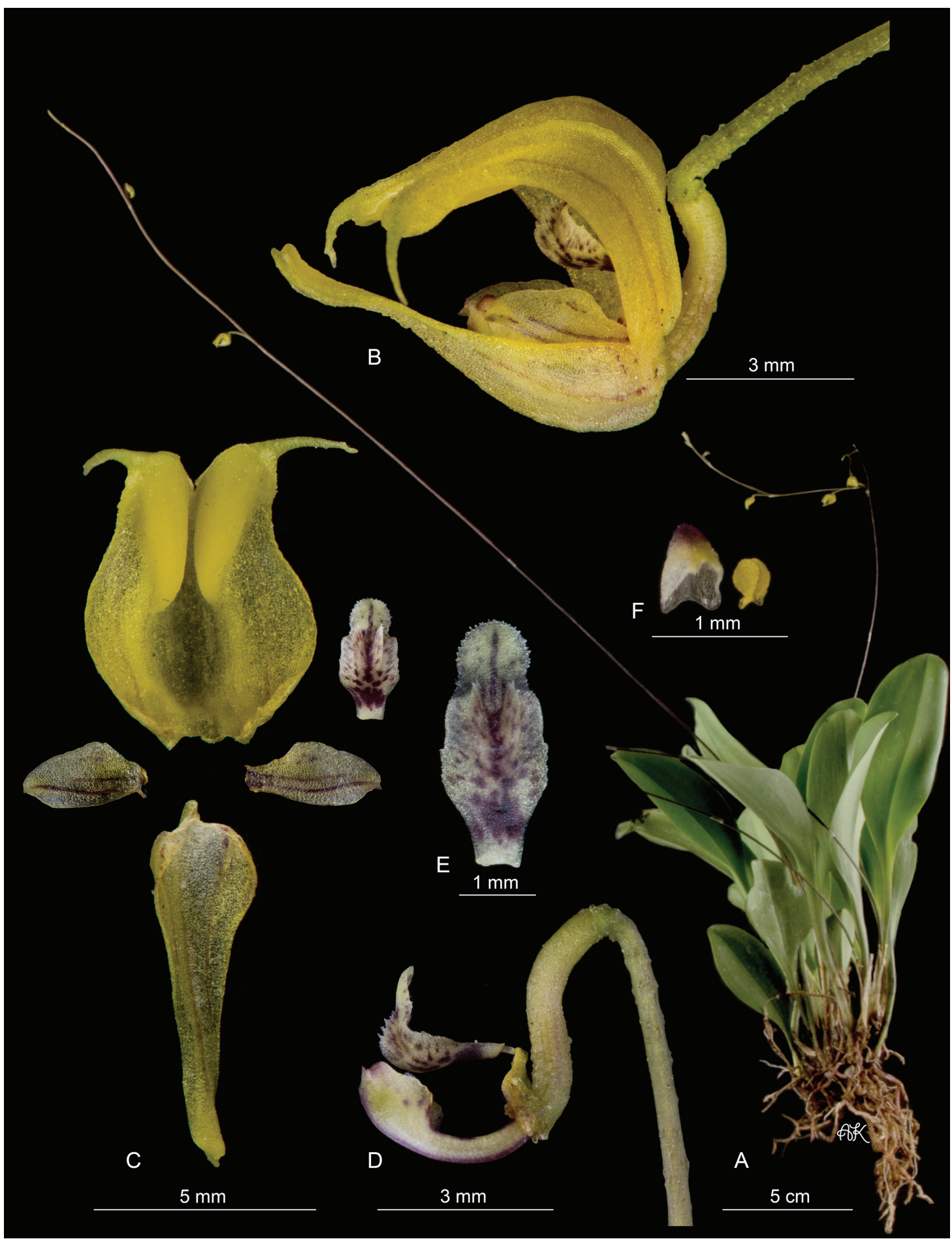

FIgure 11. Lankester Composite Dissection Plate (LCDP) of Scaphosepalum verrucosum (Rchb.f.) Pfitzer. A. Habit. B. Flower. C. Dissected perianth. D. Column and lip, lateral view. E. Lip. F. Pollinia and anther cap. Photographs by AK based on JBL-990078 (JBL-spirit). 
Madisonia. Luer, Monogr. Syst. Bot. Missouri Bot. Gard. 95: 258. 2004.

When describing Madisonia, Luer (2006) did not mention any closely related species or genera. The only known species is distinguished by a creeping rhizome and abbreviated ramicauls (both covered by ciliate sheaths); sessile, subcircular leaves; an elongated peduncle; and a single flower with a conspicuous mentum. Madisonia is indeed unique for this combination of features, and there are only two genera that would have somewhat similar species, Anathallis and Pabstiella. Anathallis spiculifera (Lindl.) Luer shares the long repent habit, abbreviated ramicaul, elongated peduncle, and three-lobed lip. Also similar is Pabstiella brasilica Luer \& Toscano, which shares the repent habit, abbreviated ramicaul, elliptical leaves, elongate peduncle, single flowers, connate lateral sepals, and three-lobed lip. It is hard to believe these three species belong to different genera, but it is too soon to say if they are indeed sister species and if they should be assigned to either Anathallis, Madisonia or Pabstiella. Luer and Toscano (2012) clearly had the same issue with these species; when describing Pabstiella brasilica their comparative description was made with a species they believed belongs to a different genus, Anathallis spiculifera. This is highly unusual because one normally compares a species with its closest relative, which of course cannot be a species from an unrelated genus. DNA data will surely be helpful in placing these three species in the future.

Conclusions. Whether more and narrowly defined or less and broadly circumscribed genera should be recognized is constantly being debated among botanists and hobbyists alike. Pleurothallidinae with 160 proposed generic names today is probably among the most debated groups in that sense. As circumscribed in Genera Orchidacearum (GO), the subtribe included only 37 accepted genera (Pridgeon 2005). Considering there are currently more than 5100 accepted species in the subtribe, Pleurothallidinae would average about 138 species per genus. That is, as defined in GO, more than double the average number of species per genus in Laeliinae, five times that average in Oncidiinae, and more than ten times the average in Zygopetalinae. There are possibly two basic explanations for this difference -- either speciation within Pleurothallidinae has been more explosive than in the others, or there is some sort of size-related bias. The answer is most likely both. Givnish et al. (2015) showed that Pleurothallidinae has one of the highest species diversification rates in the Orchidaceae. With just above 10 My of age, the subtribe is about one third younger than Laeliinae and Oncidiinae and has more than double the number of species. This means, in general terms, not only that speciation has been faster in Pleurothallidinae as compared to Laeliinae and Oncidiinae, but also that the genera belonging to the latter have had more evolutionary time to establish and differentiate. On the other hand, size does matter. We have a harder time finding and accepting morphological differences as significant in smaller organisms, especially if those organisms come in large numbers. It is in that sense to be expected that genera and species in Pleurothallidinae are more broadly circumscribed than in other orchid groups. Nevertheless, we should take care not to mask relevant speciation events and lineage diversification by being too inclusive. It is our main task to document and describe biodiversity even when that means having more names than one can remember. We are after all dealing with a subtribe that includes about $20 \%$ of all known orchids.

In this update of the phylogenetic relationships within Pleurothallidinae, 44 genera with 5114 species are recognized. However, it is clear that much more work needs to be done in the future to fully resolve and understand the systematic placement of all lineages within this megadiverse subtribe. The generic circumscriptions of Acianthera, Masdevallia, Phloeophila, Pleurothallis, Specklinia, and Stelis are, irrespective of species numbers, extremely inclusive and might not be as informative as we would like. Nevertheless, they are grossly monophyletic, and thus it is a good starting point for their reconsideration with additional evidence. It is important to take into consideration that dozens of Pleurothallidinae are described each year and that whole lineages might still need recognition. The placement of species in discrete, manageable groups makes it easier to study them in detail and normally results in the recognition of additional species. The subtribe will surely grow by several hundred species in the coming decades as more literature becomes available. The growth in species numbers will certainly be accompanied by the need for 
more generic and subgeneric taxa. As Lindley (1842) eloquently put it when discussing the pleurothallids, "they have moreover been insufficiently classified, in consequence of which the difficulty of their determination has been much increased."
AcKnowledgements. I wish to thank Franco Pupulin for encouraging the preparation of this manuscript. Alec Pridgeon and an anonymous reviewer kindly improved an earlier version of this manuscript with their comments.

\section{LITERATURE CITED}

Abele, A. D. (2007). Phylogeny of the genus Masdevallia Ruiz et Pav. based on morphological and molecular data. Ph.D. thesis, University of Hamburg, Germany, Dec 2007.

Bogarín, D., Karremans, A. P. \& Pupulin, F. (2008). New species and records of Orchidaceae from Costa Rica. Lankesteriana 8(2): 53-74.

Bogarín, D., Karremans, A. P., Rincón, R. \& Gravendeel, B. (2013). A new Specklinia (Orchidaceae: Pleurothallidinae) from Costa Rica and Panama. Phytotaxa 115(2): 31-41.

Borba, E. L., Barbosa, A. R., Cabral de Melo, M., Loureiro, S. \& Ornellas de Oliveira, H. (2011). Mating systems in the Pleurothallidinae (Orchidaceae): evolutionary and systematic Implications. Lankesteriana 11(3): 207-221.

Chiron, G. R., Guiard J. \& van den Berg, C. (2012) Phylogenetic relationships in Brazilian Pleurothallis sensu lato (Pleurothallidinae, Orchidaceae): evidence from nuclear ITS rDNA sequences. Phytotaxa 46: 34-58.

Chiron, G. R., Karremans, A. P. \& van den Berg, C. (2016) Nomenclatural notes in the Pleurothallidinae (Orchidaceae): Phloeophila. Phytotaxa 270: 56-62.

Endara, L., Williams, N. H. \& Whitten, W. M. (2011). Filogenia molecular preliminar de Scaphosepalum (Orchidaceae: Pleurothallidinae). Lankesteriana 11(3): 245-252.

Forster, W. (2007). Estudo taxonômico das espécies com folhas planas a conduplicadas do gênero Octomeria R.Br. (Orchidaceae). Doctoral Thesis. Universidade de São Paulo, São Paulo.

Garay, L.A. (1979) Systematics of the genus Stelis Sw. Botanical Museum Leaflets 27: 167-259.

Givnish, T. J., Spalink, D., Ames, M, Lyon, S. P., Hunter, S. J., Zuluaga, A., Iles, W. J. D, Clements, M. A., Arroyo, M. T. K., Leebens-Mack, J., Endara, L, Kriebel. R., Neubig, K. M., Whitten, W. M., Williams, N. H. \& Cameron, K. M. (2015). Orchid phylogenomics and multiple drivers of their extraordinary diversification. Proceedings Royal Societ $B$ 282: 20151553.

Karremans, A. P. (2010) Phylogenetics of Stelis (Orchidaceae: Pleurothallidinae) and closely related genera, based on molecular data, morphological characteristics and geographical distribution in the Central American and Andean Cordilleras. MSc Thesis, Plant Sciences Group and Biosystematics Group, Wageningen University.

Karremans, A. P. (2014). Lankesteriana, a new genus in the Pleurothallidinae (Orchidaceae). Lankesteriana 13(3): 319-332.

Karremans, A. P. (2015). Systematic, phylogenetic and pollination studies of Specklinia (Orchidaceae). Dissertation Thesis, Leiden University, The Netherlands.

Karremans, A. P. \& Rincón-González, M. (2015). Nomenclatural notes in the Pleurothallidinae (Orchidaceae): Apodaprorepentia. Phytotaxa 238(2): 174-182.

Karremans, A. P., Albertazzi, F. J., Bakker, F. T., Eurlings, M. C. M., Pridgeon, A., Pupulin, F. \& Gravendeel, B. (in press) Phylogenetic reassessment of Specklinia and its allied genera in the Pleurothallidinae (Orchidaceae). Phytotaxa.

Karremans, A. P., Bakker, F. T., Pupulin, F., Solano-Gómez, R. \& Smulders, M. J. M. (2013a). Phylogenetics of Stelis and closely related genera (Orchidaceae: Pleurothallidinae). Plant Systematics and Evolution 29(1): 69-86.

Karremans, A. P., Pupulin, F. \& Gravendeel, B. (2013b). Taxonomy, molecular phylogenetics, reproductive isolation, and niche differentiation of the Specklinia endotrachys species complex (Orchidaceae: Pleurothallidinae). Lankesteriana 13(1-2): 132-133.

Lindley, J. (1842). Pleurothallis. Edwards's Botanical Register 28: 67-84.

Lindley, J. (1859). Folia Orchidacea. Pleurothallis.

Luer, C. A. (1986a). Icones Pleurothallidinarum I. Systematics of the Pleurothallidinae (Orchidaceae). Monographs in Systematic Botany from the Missouri Botanical Garden 15.

Luer, C. A. (1986c). Icones Pleurothallidinarum III. Systematics of the genus Pleurothallis (Orchidaceae). Monographs in Systematic Botany from the Missouri Botanical Garden 20.

Luer C. A. (1991). Icones Pleurothallidinarum VIII Systematics of Lepanthopsis, Octomeria Subgenus Pleurothallopsis, 
Restrepiella, Restrepiopsis, Salpistele, and Teagueia (Orchidaceae). Monographs in Systematic Botany from the Missouri Botanical Garden 39.

Luer, C. A. (2000a). Icones Pleurothallidinarum. XX. Systematics of Jostia, Andinia, Barbosella, Barbrodia, Pleurothallis subgen. Antilla, subgen. Effusia, subgen. Restrepioidia. Addenda to Lepanthes, Masdevallia, Platystele, Pleurothallis, Restrepiopsis, Scaphosepalum, and Teagueia. Monographs in Systematic Botany from the Missouri Botanical Garden 79.

Luer, C. A. (2000b). Icones pleurothallidinarum. XXI. Systematics of Masdevallia part two. Monographs in Systematic Botany from the Missouri Botanical Garden 82.

Luer, C. A. (2002a). Icones Pleurothallidinarum XXIV: A first century of new species of Stelis of ecuador, part one. Monographs in Systematic Botany from the Missouri Botanical Garden 88.

Luer, C. A. (2002b). A Systematic Method of Classification of the Pleurothallidinae Versus a Strictly Phylogenetic Method. Selbyana 23(1): 57-110.

Luer, C. A. (2004). Icones Pleurothallidinarum XXVI. Pleurothallis subgenus Acianthera and three allied subgenera. A second century of new species of Stelis of Ecuador. Epibator, Ophidion, Zootrophion. Monographs in Systematic Botany from the Missouri Botanical Garden 95.

Luer, C. A. (2005). Icones Pleurothallidinarum XXVII. Dryadella and Acronia section Macrophyllae-Fasciculatae. Monographs in Systematic Botany from the Missouri Botanical Garden 103.

Luer, C. A. (2006). Icones Pleurothallidinarum XXVIII. Reconsideration of Masdevallia, and the Systematics of Specklinia and vegetatively similar genera (Orchidaceae). Monographs in Systematic Botany from the Missouri Botanical Garden 105 .

Luer, C. A. (2007). Icones Pleurothallidinarum XXIX. A third century of Stelis of Ecuador and Systematics of ApodaProrepentia and Systematics of Miscellaneous small genera, addenda: new genera, species, and combinations (Orchidaceae). Monographs in Systematic Botany from the Missouri Botanical Garden 112.

Luer, C. A. (2009). lcones Pleurothallidinarum XXX. Lepanthes of Jamaica and Systematics of Stelis, Stelis of Ecuador, part four and addenda: systematic of Masdevallia, new species of Lepanthes from Ecuador, and miscellaneous new combinations. Monographs in Systematic Botany from the Missouri Botanical Garden 115.

Luer, C. A. \& Toscano de Brito, A. L. V. (2012). Miscellaneous new species in the Pleurothallidinae (Orchidaceae) from Brazil. Harvard Papers in Botany 17(2): 307-315.

Matuszkiewicz, A. \& Tukallo, P. (2006). Infrageneric reclassification and phylogenetic inference in the genus Masdevallia Ruiz \& Pav. - preliminary results of nrDNA based analysis. Biodiversity Research and Conservation 3-4: 213-219

Meyer, G. \& Cameron, K. M. (2009). A preliminary phylogenetic study of Dracula (Pleurothallidinae, Epidendroideae, Orchidaceae) based on plastid matK sequence data. pp. 100-114. In Pridgeon, A. M \& Suárez, J. P. (eds.) Proceedings of the Second Scientific Conference on Andean Orchids. Universidad Técnica Particular de Loja, Loja, Ecuador.

McDaniel, J. \& Cameron, K. M. (2015). Phylogenetic utility of genotyping by sequencing (GBS) at the species level: an example from flowering plants (Porroglossum: Orchidaceae). Abstract - Botany 2015, Botanical Society of America Annual Meeting, Edmonton, Canada.

Neyland, R., Urbatsch, L. E. \& Pridgeon, A. M. (1995). A phylogenetic analysis of subtribe Pleurothallidinae (Orchidaceae). Botanical Journal of the Linnaean Society 117: 13-28.

Pessoa, E., Valsko, J. J., Vasconcelos, S., Benko-Isepon, A. M., \& Alves, M. (2014). Anathallis roseopapillosa (Orchidaceae - Pleurothallidinae) from the Central Amazon Region. Systematic Botany 39(4): 1070-1075.

Pridgeon, A. M. \& Chase, M. W. (2001). A phylogenetic reclassification of Pleurothallidinae (Orchidaceae). Lindleyana 16(4): 235-271.

Pridgeon, A. M., Solano-Gómez, R. \& Chase, M. W. (2001). Phylogenetic relationships in Pleurothallidinae (Orchidaceae): combined evidence from nuclear and plastid DNA sequences. American Journal of Botany 88(12): 2286-2308.

Pridgeon, A. M. (2005). Subtribe Pleurothallidinae. In: A. M. Pridgeon, P. J. Cribb, M. W. Chase \& F. N. Rasmussen (eds.), Genera Orchidacearum. Volume 4 Epidendroideae (Part One). Pp. 319-422.

Solano-Gómez, R. (2003). Acianthera unguicallosa (L.O.Williams) Solano. Pl. 512. In: Hágsater, E. \& Soto, M. A. (eds.). Orchids of Mexico, parts 2 and 3. Icones Orchidacearum 5 \& 6: pl. 501-700.

Solano-Gómez, R. (2005). Inference of the phylogenetic relationships in Stelis sensu lato clade based upon morphology and sequences of the ITS region data sets. In Raynal-Roques, A., Roguenant, A. \& Prat, D. (eds.) Proceedings of the 18th World Orchid Conference, March 2005, Dijon, France.

Solano-Gómez, R. (2015). A taxonomic synopsis of the Mexican species of Acianthera (Orchidaceae: Pleurothallidinae) including a new species. Phytotaxa 218(1): 93-60.

Stenzel, H. (2000). Pollen morphology of the subtribe Pleurothallidinae Lindl. (Orchidaceae). Grana 39: 108-125.

LANKESTERIANA 16(2). 2016. (C) Universidad de Costa Rica, 2016. 
Stenzel, H. (2004). Systematics and evolution of the genus Pleurothallis R. Br. (Orchidaceae) in the Greater Antilles. Dissertation Thesis. Mathematisch-Naturwissenschaftlichen Fakultät I der Humboldt- Universität zu Berlin.

Stenzel, H. (2007). Orchidaceae II. Pleurothallidinae 1. Pp. 1-152 in W. Greunter \& R. Rankin Rodríguez, eds. Flora de la Republica de Cuba. Fascicle 12(2). Gantner, Liechtenstein.

Wilson, M., Belle, C., Dang, A., Hannan, P., Kellogg, L., Kenyon, C., Low, H., Mochizuki, A., Nguyen, A., Sheade, N., Shan, L., Shum, A., Stayton, T., Volz, C., Vosburgh, B., Wellman, H. \& Woolley, M. A. (2013). Preliminary phylogenetic analysis of Pleurothallis sensu lato based upon nuclear and plastid sequences. (Abstract of poster presented at 4th Scientific Conference on Andean Orchids, November 2012, Guayaquil, Ecuador.) Lankesteriana 13(1-2):139.

Wilson, M., Frank, G. S., Jost, L., Pridgeon, A. M., Vieira-Uribe, S., \& Karremans, A. P. (in press). Phylogenetic analysis of Andinia (Orchidaceae: Pleurothallidinae) and a systematic re-circumscription of the genus. Phytotaxa. 
LANKESTERIANA • V SCIENTIFIC CONFERENCE ON ANDEAN ORCHIDS 